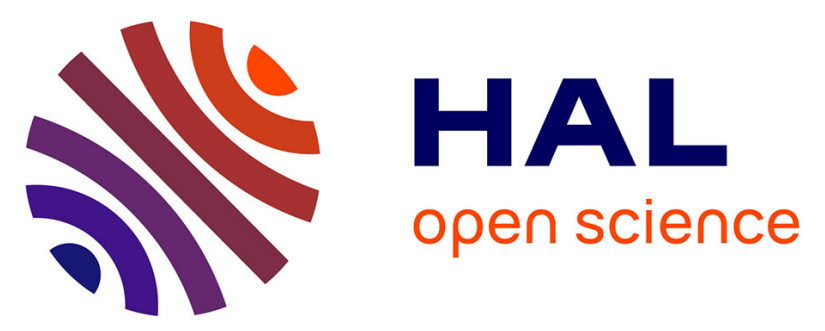

\title{
Mucin modified SPR interfaces for studying the effect of flow on pathogen binding to Atlantic salmon mucins
} János Tamás Padra, Quentin Pagneux, Julie Bouckaert, Roxana Jijie, Henrik Sundh, Rabah Boukherroub, Sabine Szunerits, Sara Lindén

\section{- To cite this version:}

János Tamás Padra, Quentin Pagneux, Julie Bouckaert, Roxana Jijie, Henrik Sundh, et al.. Mucin modified SPR interfaces for studying the effect of flow on pathogen binding to Atlantic salmon mucins. Biosensors and Bioelectronics, 2019, 146, pp.111736. 10.1016/j.bios.2019.111736 . hal-02367926

\section{HAL Id: hal-02367926 https://hal.science/hal-02367926}

Submitted on 4 Feb 2020

HAL is a multi-disciplinary open access archive for the deposit and dissemination of scientific research documents, whether they are published or not. The documents may come from teaching and research institutions in France or abroad, or from public or private research centers.
L'archive ouverte pluridisciplinaire HAL, est destinée au dépôt et à la diffusion de documents scientifiques de niveau recherche, publiés ou non, émanant des établissements d'enseignement et de recherche français ou étrangers, des laboratoires publics ou privés. 


\section{Mucin modified SPR interfaces for studying the effect of flow on pathogen binding to Atlantic salmon mucins}

János Tamás Padra ${ }^{1}$, Quentin Pagneux ${ }^{2}$, Julie Bouckaert ${ }^{3}$, Roxana Jijie ${ }^{2}$, Henrik Sundh ${ }^{4}$, Rabah Boukherroub ${ }^{2}$, Sabine Szunerits ${ }^{2 *}$, Sara K. Lindén ${ }^{1 *}$

${ }^{1}$ Department of Medical Chemistry and Cell Biology, University of Gothenburg, Gothenburg SE-405 30, Sweden

${ }^{2}$ Univ. Lille, CNRS, Centrale Lille, ISEN, Univ. Valenciennes, UMR 8520 - IEMN, F-59000 Lille, France

${ }^{3}$ Unité de Glycobiologie Structurale et Fonctionnelle (UGSF), Univ. Lille, CNRS, UMR 8576, 59658 Villeneuve d'Ascq, France

${ }^{4}$ Department of Biological and Environmental Sciences, University of Gothenburg, Gothenburg, Sweden.

To whom correspondence should be sent : $\underline{\text { sara.linden@biomedicine.gu.se }}$ SL); $\underline{\text { abine.szunerits@ } \text { univ- }}$ lille.fr (SS) 


\begin{abstract}
Knowledge on host-pathogen interactions contributes to the development of approaches to alleviate infectious disease. In this work, we developed a surface plasmon resonance (SPR) based method for investigating bacteria/mucins interactions. Furthermore, we investigated adhesion of three pathogens, Aeromonas salmonicida, Aeromonas hydrophila and Vibrio harveyi, to Atlantic salmon mucins isolated from different epithelial sites, using SPR and microtiter-based binding assays. We demonstrated that performing bacterial binding assays to mucins using SPR is feasible and has advantages over microtiter-based binding assays, especially under flow conditions. The fluid flow in the SPR is linear and continuous and SPR enables real-time reading of mucin-bacterial bonds, which provides an in vivo-like setup for analysis of bacterial binding to mucins. The variation between technical replicates was smaller using SPR detection compared to the adenosine 5'-triphosphate (ATP) bioluminescence assay in microtiter plates. Furthermore, we demonstrated that the effect of flow on pathogen-mucin interaction is significant and that bacterial adhesion differ non-linearly with flow rates and depend on the epithelial source of the mucin.
\end{abstract}

Keywords: surface plasmon resonance, mucin, Aeromonas salmonicida, Vibrio harveyi, Aeromonas hydrophila, Atlantic salmon 


\section{Introduction}

Understanding host-pathogen interactions has become essential to limit the constraints infectious diseases impose on salmonid aquaculture as well as to society at large. The first point of contact between pathogens and fish is the mucus layer, built of highly glycosylated gelforming mucins (Linden et al., 2008b). In Atlantic salmon, mucins of the skin carry short, relatively simple $O$-glycans, whereas the intestinal mucins carry complex and predominantly branched glycans (Padra et al., 2014; Jin et al., 2015; Benktander et al., 2019). Studies on human gastric mucosal pathogens suggest that carrying mucin glycans that bind to pathogens are of benefit to the host, limiting the number of pathogens that reach the epithelial cell surface (Linden et al., 2009; Linden et al., 2008a; Linden et al., 2010) However, for tissues like the fish skin and gills exposed to pathogens dispersed in the surrounding water, mucins with neglectable pathogen interactions may be more beneficial as the pathogens can be washed off by the passing water, thereby minimizing pathogen adherence (Padra et al., 2014; Padra et al., 2019a). To evaluate the interactions of pathogens with fish mucins biochemical assays are routinely employed. These assays are rather time consuming and can have a relatively large variation in the signal to noise ratio. Underlying factors in the high variance includes the necessity of several treatment and washing steps, temperature sensitive detection systems and crosstalk between plate wells. The use of antibodies in the detection step can result in nonspecific protein interactions while bacteria can also nonspecifically bind to the plate well, depending on the efficiency of the blocking. Some detection systems are based on the metabolic health of bacteria, which further complicates reliable quantification of binding, especially since certain mucin glycans have a growth modulating effect on some pathogens (Padra et al., 2019b; Padra et al., 2017; Padra et al., 2019c). These glycans can change with infection, and therefore comparisons between avidity between groups of individuals with different health status is a particular concern. Previously, we used angular speeds to mimic the swimming speed of fish (Padra et al., 2019a). In such experimental setup, a microtiter-plate is rotated, and the bacterial suspension moves towards the edge of the well bottom with increasing speeds. Despite that this method gives an insight into liquid flow related changes of mucin-bacterial interactions, the different liquid distribution within the well with different rotational speed as well as differences in centrifugal force between devices complicates the translation of angular speed to the shear force bacteria are subjected to on epithelial surfaces in vivo.

Current strategies for protection against bacterial infections in aquaculture are challenged by that not all vaccines are efficacious and by vaccination side effects including peritonitis (Bjørge 
et al., 2011), soft tissue adhesions (Midtlyng, 1997), skeletal deformities (Berg et al., 2019), reduced feed intake and reduced swimming activity (Bjørge et al., 2011). Due to these negative physical health and behavioral effects, both the productivity of aquaculture and the welfare of the fish are affected. As a better understanding of mucin-pathogen interactions is important to ease the economic burden and reduced welfare that infectious diseases impose on salmonid aquaculture, improvement and broadening of analytic approaches in this research field has become essential.

Surface plasmon resonance (SPR), a technique monitoring changes of the local optical density (reflectivity) upon a surface binding event, is an attractive technique for the evaluation of bacterial binding events to modified surfaces (Safina, 2012; Subramanian et al., 2014; Zagorodko et al., 2015). SPR experiments are routinely performed either under static conditions or under flow, where the flow rate can be changed between $7-100 \mu \mathrm{L} \mathrm{min}^{-1}$ (Szunerits et al., 2016; Zagorodko et al., 2015). This allows mimicking in vivo conditions more precisely, such as the binding ability of pathogens to fish mucins during fluid flow. In many circumstances, bacterial cells are suspended in a flowing fluid carrier (water, saliva, blood, urine etc.) and thus investigating bacterial cell adhesion dynamics under controlled fluid flow conditions is relevant. This is especially pertinent for studies on aquatic species, as the interaction of pathogens with fish mucins is influenced by the fluid velocity (Padra et al., 2019b), which indicate that swimming speed of fish/water current speed is important to take into account.

The present paper deals with three significant aquatic pathogens. Aeromonas salmonicida, which causes furunculosis in a variety of aquatic animals, mainly salmonids, and the adhesion and growth of which is governed by mucin glycans. $O$-glycans terminating in $\mathrm{N}$ acetylneuraminic acid (NeuAc) provide binding sites for A. salmonicida and the presence of hexosaminoglycans enhance its growth. Vibrio harveyi also infects Atlantic salmon (Zhang and Austin, 2000) and the GM4 ganglioside (NeuAca2,3Galß1Cer) has been indicated as a $V$. harveyi attachment epitope on red sea bream intestinal epithelial cells (Chisada et al., 2013; Lee et al., 2002). Aeromonas hydrophila cause motile Aeromonas septicemia (MAS) in freshwater fish (Zhang et al., 2016). This pathogen frequently infects rainbow trout (Mittal et al., 1980; Zepeda-Velázquez et al., 2015; Çagatay and Şen, 2014) and has been found in contact with the distal intestinal wall of Atlantic salmon and Arctic char (Ringø et al., 1997).

A thorough understanding of host pathogen interactions at the host surfaces can enable development of novel therapeutic interventions to prevent and cure infection, by for example increasing mucin production rate, affecting the host mucin glycosylation machinery or 
producing synthetic mucins for ingestion. This is especially important due the increasing problem of antibiotic resistance. The current study uses fish mucins and fish pathogens, however, mucins and mucin like molecules have been identified in all animals studied, including humans and farmed animals (Quintana-Hayashi et al., 2018; Lindén et al., 2002; Linden et al., 2008a). This suggests that the ability of these molecules to contribute to the defense against pathogens is a widespread phenomenon, and methods to study them can be utilized in many fields.

The objectives of the work presented are to develop and optimise a SPR-based methodology to evaluate the interactions of mucins with pathogens and to study the effect of fluid flow on bacterial binding to Atlantic salmon mucins.

\section{Materials and Methods}

\subsection{Preparation of mucin coated gold-based SPR interfaces}

Gold-based SPR interfaces were cleaned for 15 min with a UV/ozone cleaner, immersed in 11mercaptoundecanoic acid ( $1 \mathrm{mM}$, ethanol $3 \mathrm{~mL})$ for $24 \mathrm{~h}$, rinsed with ethanol (three times) and MilliQ water (five times) and stored in water. The formed $\mathrm{Au}-\mathrm{COOH}$ surface was immersed into $\mathrm{N}$-(3-dimethylaminopropyl)-N'-ethylcarbodiimide hydrochloride $(15 \mathrm{mM})$ and $\mathrm{N}$ hydroxysuccinimide (15 mM) in PBS solution (0.1 M, pH 7.4) for $40 \mathrm{~min}$. The different mucins were added to this solution to have a final protein concentration of $10 \mu \mathrm{g} \mathrm{mL}^{-1}$ and incubated for $1 \mathrm{~h}$ in the dark. The interface was rinsed with PBS and used for interaction studies immediately thereafter.

For details concerning the used SPR instrumentation and surface characterization methods see supporting information S1.

\subsection{Preparation of mucins}

2.2.1. Fish and mucin isolation: Five Atlantic salmon (250-300g) from Långhult lax, Långhult, Sweden, retained in freshwater in a recirculating Aquaculture System (RAS) at a flow of $8.5 \mathrm{~L}$ $\min ^{-1}$, were harvested as previously described.(Padra et al., 2017) Five fish were sedated with metomidate (12 $\left.\mathrm{mg} \mathrm{L}^{-1}\right)$ and killed by a hit to the head. Mucus was scraped from the skin using microscopy glass slides. The intestine was divided into a proximal and distal region and microscopy glass slides were used to scrape off the mucosa and mucus. The pyloric ceca was pulverized in liquid nitrogen using a mortar and pestle. To inhibit proteases, tissues were 
submerged in sodium dihydrogen phosphate $(10 \mathrm{mM}, \mathrm{pH}$ 6.5) containing phenylmethylsulfonyl fluoride (PMSF, 0.1 mM, pH 6.5).

2.2.2. Purification: Purification of mucins from DNA, lipids and non-mucin proteins was achieved using isopychnic density gradient centrifugation as previously described,(Padra et al., 2014) see supporting information $\mathbf{S 2}$ for details.

2.2.3. Mucin quantification (Glycan detection): The carbohydrate content of the mucin sample density gradient fractions were analyzed as periodate-oxidizable structures in a microtiter-based assay as previously described (Padra et al., 2019b). Briefly, 24-28 fractions (depending on sample) from each density gradient were diluted 1:100, 1:500 and 1:1,000 in 4 M GuHCl, coated on 96-well plates (PolySorp, NUNC A/S, Roskilde, Denmark) and incubated overnight at $4^{\circ} \mathrm{C}$. To determine which fractions that contained a high carbohydrate content, fractions were coated in singles $(n=1)$ which, supplemented with the use of three dilutions, was sufficient to obtain this type of graphs (Fig. 1A). The remainder of the protocol was carried out at $23-24{ }^{\circ} \mathrm{C}$ and the plates were washed between each step with washing solution (5 mM Tris$\mathrm{HCl}, 0.15 \mathrm{M} \mathrm{NaCl}, 0.05 \%$ Tween $\left.20,0.02 \% \mathrm{NaN}_{3}, \mathrm{pH} 7.75\right)$. The carbohydrates were oxidized for $20 \mathrm{~min}$ ( $25 \mathrm{mM}$ sodium metaperiodate, $0.1 \mathrm{M}$ sodium acetate buffer, $\mathrm{pH}$ 5.5) and DELFIA blocking solution (50 mM Tris-HCl, $0.15 \mathrm{M} \mathrm{NaCl}, 90 \mathrm{mM} \mathrm{CaCl}_{2}, 4 \mathrm{mM}$ EDTA, $0.02 \% \mathrm{NaN}_{3}$, $0.1 \%$ BSA, $\mathrm{pH} 7.75$ ) was then added for $1 \mathrm{~h}$. The wells were incubated for $1 \mathrm{~h}$ with $2.5 \mathrm{mM}$ biotin hydrazide (in $0.1 \mathrm{M}$ sodium acetate buffer, $\mathrm{pH}$ 5.5) and then with Europium-labeled streptavidin (diluted 1:1,000 in Delfia assay buffer, PerkinElmer; $50 \mathrm{mM}$ Tris- $\mathrm{HCl}, 0.15 \mathrm{M}$ $\mathrm{NaCl}, 20$ mM DTPA, $0.01 \%$ Tween 20, 0.02\% $\mathrm{NaN}_{3}, 1.5 \%$ BSA, pH 7.75). After $1 \mathrm{~h}$ incubation, the plates were incubated with Delfia enhancement solution (PerkinElmer; $0.05 \mathrm{M} \mathrm{NaOH}, 0.1$ M phthalate, $0.1 \%$ Triton X-100, $50 \mathrm{mM}$ TOPO, $15 \mathrm{mM}$ b-NTA) at $120 \mathrm{rpm}$ (rounds per minute) on an orbital shaker for $5 \mathrm{~min}$. Fluorescence $\left(\lambda_{\text {excitation }}=340 \mathrm{~nm}\right.$ and $\left.\lambda_{\text {emission }}=615 \mathrm{~nm}\right)$ was measured with the Europium label protocol. After the mucin-containing fractions were selected from the gradient (e.g. fractions 7 to 11 on Fig. 1A) they were pooled yielding one purified mucin sample for each tissue and fish. These mucins were diluted first in three steps (1:100; 1:200 and 1:400) coated on the 96-well plate in triplicates. If the target concentration (4-6 $\mathrm{ug} / \mathrm{ml}$ ) was not reached in this dilution series, another dilution series was performed until the target concentration was reached for all mucin samples. Carbohydrate quantification described above was repeated and the resulting europium values were converted to concentration based on a commercially available porcine gastric mucin (PGM, Sigma Aldrich) standard curve. A mucin sample stock of $100 \mu \mathrm{g} \mathrm{mL}^{-1}$ was prepared for subsequent analyses. 


\subsection{Culture of bacteria}

Aeromonas salmonicida subsp. salmonicida strain VI-88/09/03175 (culture collection, Central Veterinary Lab., Oslo, Norway) was cultured on Tryptic Soy Agar (TSA). A. hydrophila (ATCC 7966) was cultured on Nutrient agar (Difco) at $26^{\circ} \mathrm{C}$. V. harveyi BB170 (courtesy of Bonnie Bassler, Princeton University, USA) was cultured on Marine agar (Difco) at $26{ }^{\circ} \mathrm{C}$. Harvested colonies were then washed several times and dissolved in 1 Phosphate Buffered Saline (PBS) or freshwater media at final concentration of $1 \times 10^{8} \mathrm{CFU} \mathrm{mL}^{-1}$, which was used for the injection into the SPR device.

\subsection{ATP-based bacterial binding assays}

The assay was performed as previously described (Padra et al., 2019a). Briefly, mucins were diluted in $4 \mathrm{M} \mathrm{GuHCl} / \mathrm{PBS}$ and coated on white opaque plates (Costar) in five replicates. On each plate, five wells were coated with $4 \mathrm{M} \mathrm{GuHCl/PBS}$ serving as controls for background binding and the mean values of these wells was later subtracted from the bacterial binding values to mucins. Mucins attached to the plates at $4{ }^{\circ} \mathrm{C}$ overnight and plates were then washed three times with PBS (140 mM NaCl, $2.7 \mathrm{mM} \mathrm{KCl}, 10 \mathrm{mM}$ phosphate buffer, $\mathrm{pH}$ 7.4) containing $0.05 \%$ Tween (PBS-T). Unspecific binding to all wells (including control wells) was blocked with $200 \mu 1$ 0.5\% Bovine Serum Albumin (BSA; Sigma-Aldrich) in PBS-T (Blocking buffer) for 1 hour at $4{ }^{\circ} \mathrm{C}$ and then the blocking buffer was discarded. Bacteria were washed three times at $3,000 \times \mathrm{g}$ for $5 \mathrm{~min}$, suspended in blocking buffer $(\mathrm{pH} 7.8)$ to $\mathrm{OD}_{600}=0.1$, further diluted 1:20 and $100 \mu \mathrm{l}$ was incubated in the wells for $2 \mathrm{~h}$ at $10{ }^{\circ} \mathrm{C}$. This temperature inhibits the growth of the studied bacteria, but they remain alive. Wells were washed with chilled PBST three times and $100 \mu 1$ Bac Titer-Glo ${ }^{\text {TM }}$ reagent and $100 \mu 1$ PBS were added to the wells. Plates were incubated for $10 \mathrm{~min}$ and luminescence was read in a Clariostar plate reader (Berthold technologies). Parallel microtiter plates (Nunc PolySorp) were coated for glycan detection, i.e. mucin quantification, which allowed for normalizing the bacterial binding results for the mucin quantity. This ensured that differences in binding were not due to small mucin coating differences. Glycan detection was performed as described above with all samples coated in triplicates. Data shown were within the linear range between bacterial binding and mucin concentration to ensure reliable quantification. At lower than optimal mucin concentration, the signal to noise ratio can be low, while at too high concentration mucin layers can stack up and break off along with bound bacteria, leading to lower apparent signals. Therefore binding assays were performed at four mucin concentrations, taking into account results that were similar when the binding signal was expressed per unit of carbohydrate signal 
for at least three of the concentrations (i.e., the assay was performed within a linear range), including a glycan value of 20,000 europium counts (corresponding to approximately $4 \mu \mathrm{g} / \mathrm{ml}$ mucin). To calculate relative binding of bacteria to Atlantic salmon mucins and compare between the methods used (see Fig. 2) we summed up the binding to mucins from all organs within the same method and calculated the binding to particular sites relative to the sum of the binding.

\subsection{Binding assay with fluid velocity and speed conversion}

Linear velocity of bacterial suspension in the SPR flow chamber was calculated based on the following formula: $\mathrm{v}=\mathrm{Q} / \mathrm{A}$, where " $\mathrm{v}$ " is linear velocity, " $\mathrm{Q}$ " is volumetric flow rate and " $\mathrm{A}$ " is the cross-sectional area of the fluid perpendicular to flow $\left(A=2.5 \mathrm{~mm}^{2}\right.$ in our case: width (5 $\mathrm{mm}) \times$ height $(0.5 \mathrm{~mm})$ of the SPR chamber). The volumetric flow rates used here, that is 7 , 30,50 and $100 \mu \mathrm{L} \mathrm{min}{ }^{-1}$, therefore correspond to $2.8,12,20$ and $40 \mathrm{~mm} \mathrm{~min}^{-1}$. In the present paper, use of the term "shear force" reflects liquid flow induced shear force.

\subsection{Statistical analyses}

The Graph Pad Prism 8.0 (GraphPad Software Inc.) software package was used to perform statistical analyses. The Kolmogorov-Smirnov test and Bartlett's test were used to analyse normality and homoscedasticity of data. The hypothesis that the binding avidity of pathogens differed between mucins of different tissue origin under static fluid conditions was tested by One-way ANOVA with Tukey's multiple comparison test. The hypothesis that fluid velocity had an effect on bacterial binding to mucins was analysed by One-Way ANOVA followed by Dunnett's multiple comparisons test with the static condition used as control. The difference of error rates of SPR vs Luminescent detection was tested by Unpaired Student's T test. The level of significance was set at $p \leq 0.05$. The experimental design is visualized in a work flow chart in supporting information $\mathbf{S 3}$.

\section{Results and Discussion}

\subsection{Formation of mucin-modified gold interfaces}

The first step concerns the integration of the different fish mucin samples on gold-based SPR. To avoid non-mucin biomolecules linking to the gold surfaces, the mucins were purified by isopycnic density gradient centrifugation and were identified by a sharp carbohydratecontaining peak at $1.35 \mathrm{~g} \mathrm{~L}^{-1}$ density (Fig. 1A). Mucin containing fractions pooled for surface modification and subsequent analyses were of high purity, ensured by the absence of DNA and 
low-density carbohydrate-containing material overlapping with the mucin containing fractions (Fig. 1A).

Some attempts are described in the literature for studying mucoadhesive phenomena using SPR (Takeuchi et al., 2005; Chayed and Winnik, 2007; Bravo-Osuna et al., 2012; Dedinaite et al., 2005). Dedinaite et al. showed good adsorption efficiency of a bovine submaxillary gland mucin/chitosan complex on negatively charged SPR interfaces (Dedinaite et al., 2005). The preferential interaction of mucins with positively charged chitosan was demonstrated in parallel by Bravo-Osuna using ocular mucins (Bravo-Osuna et al., 2012). According to their results, chitosan demonstrated a statistically significant permanent chemical interaction with the transmembrane ocular mucin surface (Bravo-Osuna et al., 2012). To avoid introducing chitosan with potential to affect interactions with bacteria, we opted for the covalent linking of fish mucins to gold using 11-mercaptoundecanoic acid (MUA) as surface ligand (Stettner et al., 2009), followed by peptide linkage between the terminal-amine groups of the mucins and activated ester groups of the Au-COOH interface (Fig. 1B; for XPS survey spectra see SI Fig. S1B).

(A)

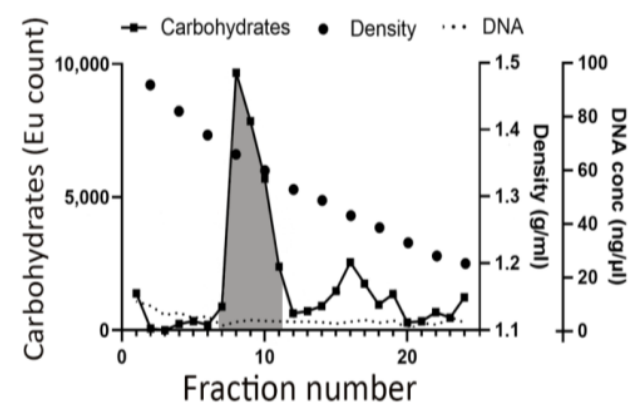

(C)

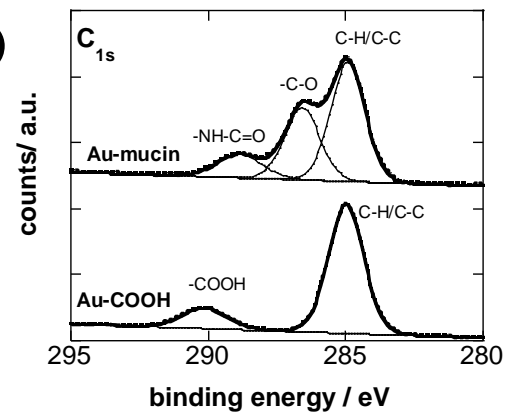

\section{PROXIMAL INTESTINE} MUCIN
(B)

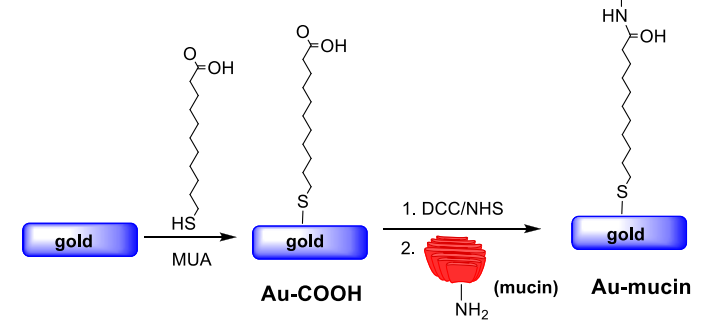

(D)
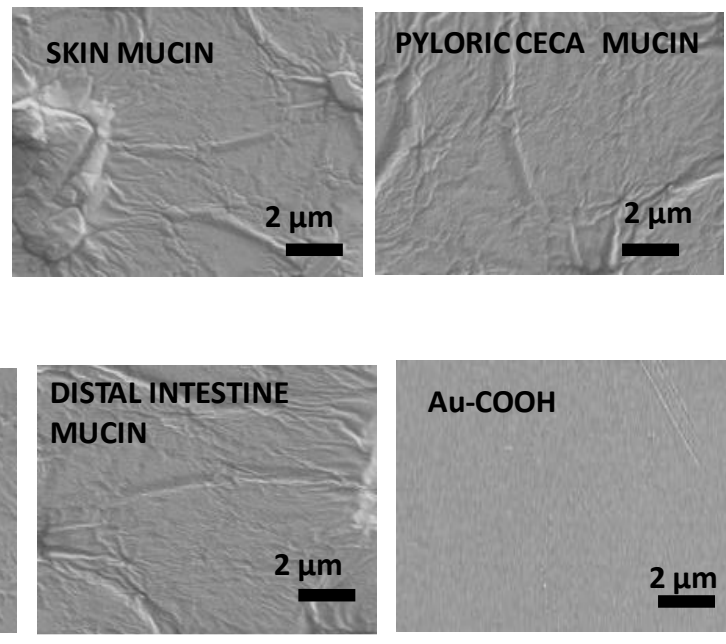

$\mathrm{Au}-\mathrm{COOH}$

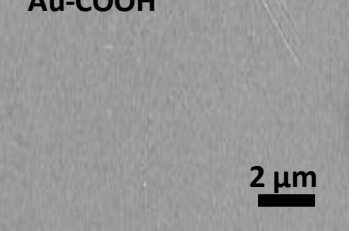


Figure 1. Mucin purification, surface modification scheme and quality control of Au-interface modified by mucins. (A) An example (distal intestinal mucus) of mucin isolation using $\mathrm{CsCl}$ density gradient ultracentrifugation. The tubes were emptied from the bottom and carbohydrate content (Europium count), density $\left(\mathrm{g} \mathrm{mL}^{-1}\right)$ and DNA content $\left(\mathrm{ng} \mu \mathrm{L}^{-1}\right)$ determined. The fractions for all samples were pooled based on the carbohydrate peaks (as indicated by the grey shade in this example). (B) Reaction scheme for the formation of mucin modified gold SPR interfaces. (C) C1s core level XPS spectra of Au-COOH and Au-mucin interfaces. (D) SEM images of mucin-modified gold interfaces.

The success of the surface modification steps was confirmed by the change in water contact angle measurements as well as in the $\mathrm{C}_{1 \mathrm{~s}}$ core level photoemission spectrum. The initial contact angle for water on bare gold thin films before the surface modification process $(\mathrm{t}=0 \mathrm{~min})$ was $66 \pm 2^{\circ}$ and decreased to $33 \pm 1^{\circ}$ after the formation of the self-assembled monolayer (SAM) of MUA at room temperature. While contact angle measurements are useful tools in the first characterisation of SAMs, XPS was employed in addition to further define elementary characterisation. The presence of the aliphatic carbon atoms of MUA results in a peak at 285.0 $\mathrm{eV}$ with terminal carboxyl groups seen at $289.1 \mathrm{eV}$. Integration of the mucins shows next to the peak at $285.0 \mathrm{eV}$, contributions at $286.2 \mathrm{eV}$ and $288.1 \mathrm{eV}$, characteristic of C-O bands of the integrated mucin and the formed amide bond become visible (Fig. 1C). SEM images confirm the presence of a mucin film on the gold interfaces (Fig. 1D). In contrast to $\mathrm{Au}-\mathrm{COOH}$, with a flat surface aspect, mucin modified interfaces have a rougher surface aspect; although minor local micro heterogeneity was present in the mucin distribution on the gold surfaces, the deposit was similar for mucins from the different epithelia. Mucin deposition on gold yields welldefined SPR curves, with a shift of the SPR minimum to higher angles (see SI, Figure S1). SPR fittings determined the mucin layer thicknesses as 8-10 $\mathrm{nm}$ when using a refractive index of 1.346 (Dedinaite et al., 2005) with an adsorbed amount of mucin of about $425 \pm 15 \mathrm{pg} \mathrm{mm}^{-2}$, comparable to the reported mucin/chitosan deposits by Dedinaite et al.

\subsection{SPR on mucin-modified gold interfaces}

A key issue in understanding the biology of mucin layers relates to what adheres to them. This might be particularly important in Atlantic salmon, where viscous mucus films that differ in glycosylation are present in the different parts of the fish (skin, pyloric ceca, proximal and distal intestines). The mucus might be a primary causative mediator to attract or repel certain pathogenic bacteria. The mucin-modified interfaces were thus challenged in SPR experiments with three different pathogens. 


\subsubsection{Pathogen binding under static fluid conditions}

The interactions between A. salmonicida, A. hydrophila and V. harveyi $\left(10^{8} \mathrm{CFU} \mathrm{mL}^{-1}\right)$ and the different Au-mucin interfaces were first investigated in real time using SPR under static fluid conditions (Fig. 2). SPR signals with all pathogens and mucins were above the background level $(\mathrm{p} \leq 0.05)$, except for $A$. hydrophila binding to proximal intestinal mucins ( $\mathrm{p}=$ not significant $/ \mathrm{ns} /, \mathrm{n}=3$ ). To compare the avidity of the three pathogens to mucins from different epithelial sites and across methods, we expressed the data in percentage of total binding to mucins from all epithelial sites. Using SPR detection, A. salmonicida bound with higher avidity to mucins isolated from the pyloric ceca and distal intestine than to those isolated from the skin and proximal intestine $(\mathrm{p} \leq 0.0001, \mathrm{n}=3)$. A. hydrophila had highest avidity to pyloric cecal mucins followed by distal intestinal and skin mucins in decreasing order of binding avidity $(\mathrm{p} \leq 0.0001, \mathrm{n}=3)$. V. harveyi bound similarly to all mucin types. The binding was however $25 \%$ lower to skin mucins compared to the other mucin groups $(\mathrm{p} \leq 0.001, \mathrm{n}=3)$. Lower binding of all three bacteria to skin mucins compared to pyloric cecal and distal intestinal mucins is a phenomenon we noted previously for A. salmonicida (Padra et al., 2014) and A. hydrophila (Padra et al., 2019a). This could be a host defence mechanism to limit pathogens from establishing contact with the body surface of fish. Binding of internal mucins however can have the opposite role: movement of bacteria towards epithelial cells is reduced by entrapment and shedding of the mucus can help rid the body of pathogens by acting as releasable decoys (Linden et al., 2009). All of the Atlantic salmon internal epithelia can host bacteria (Navarrete et al., 2009) and adaptations in mucin glycosylation to nurture these commensals, through colonization and mucus foraging, are likely to have an effect on pathogenic bacteria as well. The microbiota of Atlantic salmon can vary greatly between farmed and wild populations (Lavoie et al., 2018). Recently, Fogarty et al. found higher bacterial diversity in the proximal intestine of farmed Atlantic salmon than that of the distal intestine (Fogarty et al., 2019). We previously determined that $A$. salmonicida grow faster in the presence of proximal intestinal mucins and that the underlying factor is the GlcNAc residue on mucin glycans (Padra et al., 2017). Furthermore, increased binding to human gastric mucins, through the aggregation of bacteria, inhibited the growth of Helicobacter pylori (Skoog et al., 2017). Considering the role of mucins alone, low or no binding of the two Aeromonas spp. to proximal intestinal mucins and the above-mentioned findings suggest proximal intestinal mucins to provide the least protection against these pathogens. $V$. harveyi on the other hand did not show a particular preference for any of the three gastrointestinal sites. 
When compared to ATP-based detection of bound bacteria to mucin-modified plastic interfaces in a microtiter plate format, similar adhesion trends were observed. $V$. harveyi adhesion was relatively uniform to different Atlantic salmon mucins whereas A. salmonicida and $A$. hydrophila adhesion depended on the tissue origin of mucins. The results of the SPR detection method and the ATP-based detection method across all pathogen species and all mucin groups correlated positively $(r=0.7, p=0.011)$. Furthermore, the interaction profiles as determined by SPR and ATP-bioluminescence microtiter plate detection were validated visually by the SEM images recorded on the different Au-mucin interfaces after interaction of the three different pathogens for 60 min (Fig. 3). Despite the lack of statistical evidence for the binding of $A$. hydrophila in the SPR setup, SEM images suggest that A. hydrophila has a weak affinity to proximal intestinal mucins, albeit to a lower degree than to the other mucins (Fig. 3B).

The temperature in waters that Atlantic salmon lives in is normally between $0-20{ }^{\circ} \mathrm{C}$, while infections with the pathogens studied here occur in the higher temperature range $\left(>16^{\circ} \mathrm{C}\right)$. The ATP-based assays were performed at $10{ }^{\circ} \mathrm{C}$ to minimize the pathogen growth modulating effects of mucins (Padra et al., 2017). However, we have previously obtained similar $A$. salmonicida-Atlantic salmon mucin binding results at $22{ }^{\circ} \mathrm{C}$ when performing a comparable assay using a different detection system (Padra et al., 2014). The SPR based assays were performed at $24{ }^{\circ} \mathrm{C}$, suggesting that temperatures in this range do not have major effects on the adhesins. Pathogen concentrations can vary enormously in the local environment, however, as the mucin concentrations is low in the assays compared to the in vivo mucosal surface, the bacteria to mucin ratio is likely higher in the assay performed here than most in vivo situations. 
(A)

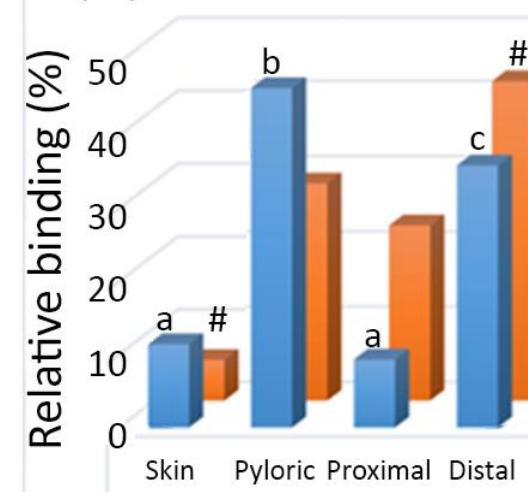

A. salmonicida
(B)

b

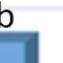

(C)

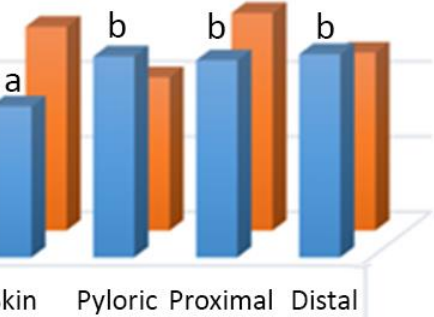

V. harveyi

\section{SPR $\square$ Lum}

Figure 2. Relative binding of bacteria $\left(10^{8} \mathrm{CFU} \mathrm{mL}^{-1}\right)$ to Atlantic salmon mucins in a microtiterbased (orange) and an SPR setup (blue) under static conditions. Relative binding of: (A) A. salmonicida (SPR: $\mathrm{p} \leq 0.0001, \mathrm{n}=3$; Lum: ATP detection by luminescence: $\mathrm{p} \leq 0.05, \mathrm{n}=5$ ), (B) A. hydrophila (SPR: $\mathrm{p} \leq 0.0001, \mathrm{n}=3$; ATP detection: $\mathrm{p} \leq 0.001, \mathrm{n}=5$ ) and (C) V. harveyi (SPR: $\mathrm{p} \leq 0.001$, $\mathrm{n}=3$; ATP detection: $\mathrm{p}=\mathrm{ns}, \mathrm{n}=5$ ). Variance between technical replicates is described in Figure 5. The results are expressed as the proportion (\%) binding to mucins from each epithelial site relative to the sum of the binding to mucins from all epithelia within each method. Statistics: One-way ANOVA with Tukey's multiple comparison test. \# statistical difference between skin and distal intestine using the ATP based assay; a, b, c and d letters denote significant differences within each pathogen species using the SPR method. Values denoted by the same letter are not statistically different from each other but from those having a different letter. Abbreviations: pyloric: pyloric cecal mucins, proximal: proximal intestinal mucins and distal: distal intestinal mucins. The results were reproduced three times. 
(A) A. salmonicida
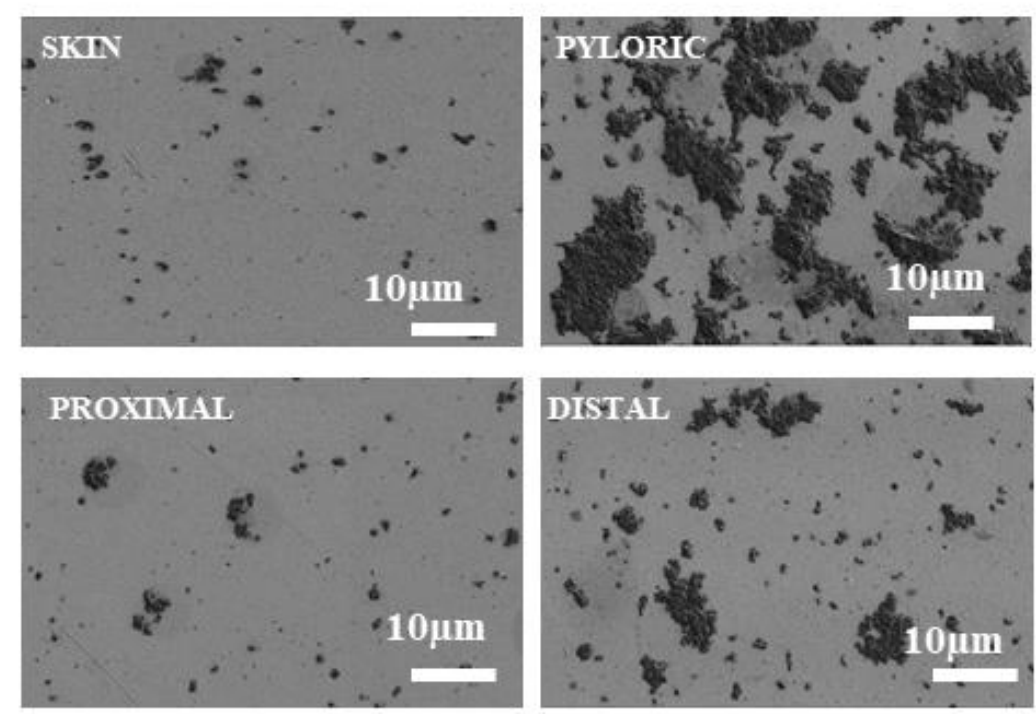

(B) A. hydrophila
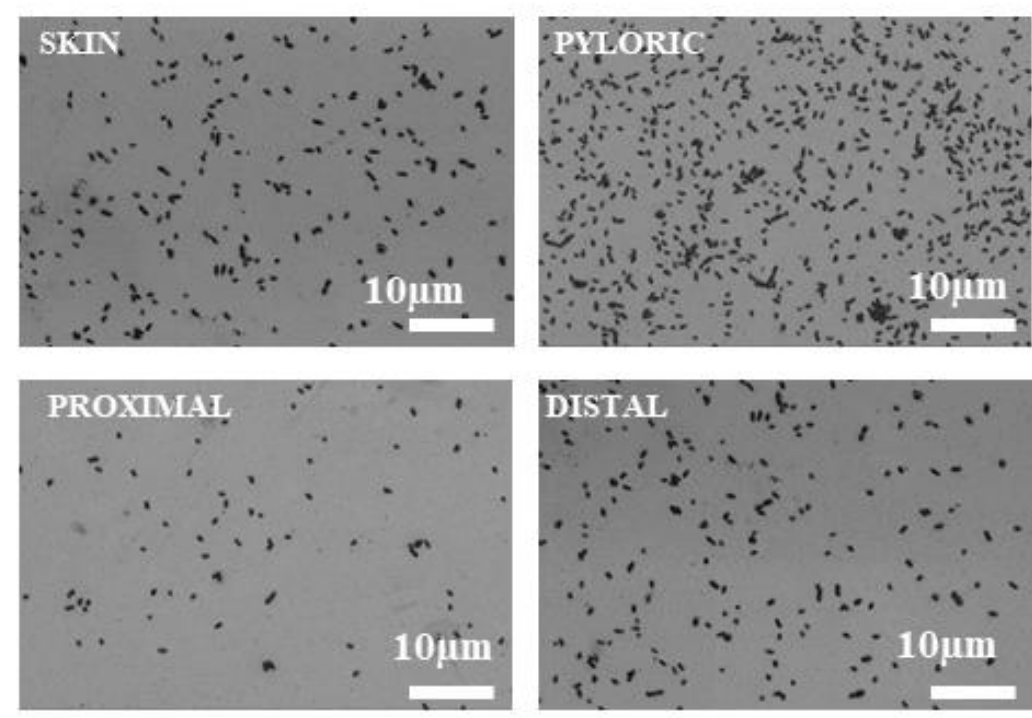

(C) V. harveyi
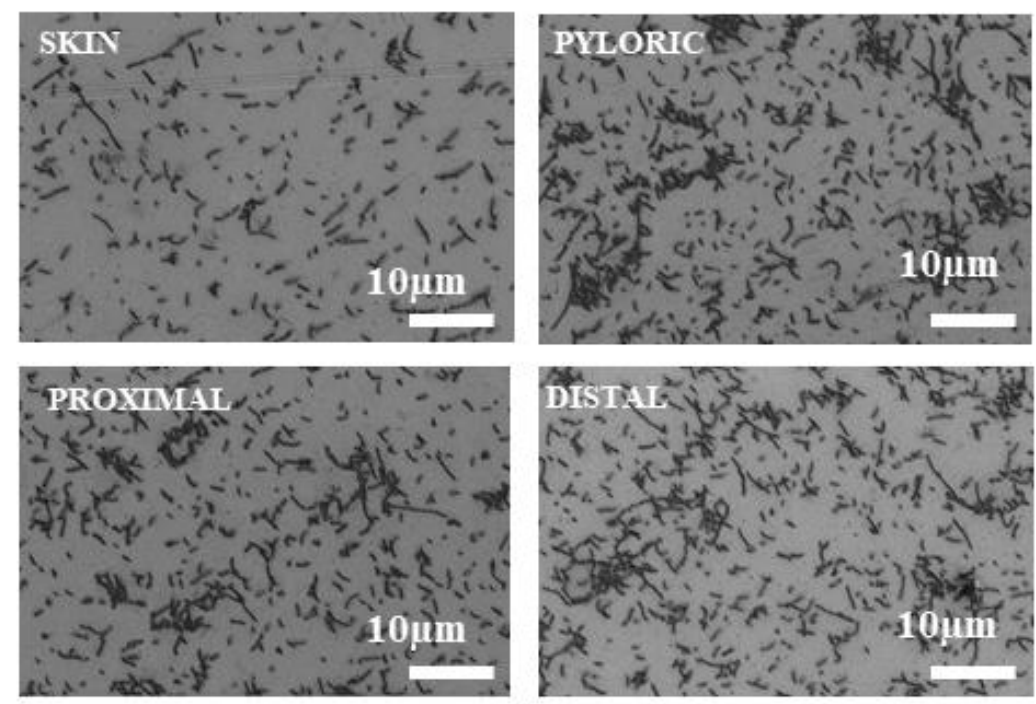
Figure 3. SEM images of bacteria bound to mucins. (A) A. salmonicida, (B) A. hydrophila and (C) $V$. harveyi binding to gold SPR interfaces modified with skin, pyloric cecal, proximal and distal intestinal mucins upon interaction with bacteria $\left(10^{8} \mathrm{CFU} \mathrm{mL}^{-1}\right)$ for $60 \mathrm{~min}$. (A) A. salmonicida binding to the mucin layer is biofilm-like with the formation of bacterial aggregates. (B) A. hydrophila binds to the mucin layer with low levels of aggregation. (C) V. harveyi binds to the mucin layer forming filamentlike aggregates. The figure shows images representative of the gold chips.

\subsubsection{Pathogen binding under flow conditions}

Fluid flow affect host-microbial interactions (Padra et al., 2019a). Flow can be controlled in the flow chamber of the SPR cell (Zagorodko et al., 2015; Szunerits et al., 2016) and therefore we investigated the influence of flow rate on the binding avidity of A. salmonicida, A. hydrophila and $V$. harveyi to different mucin modified interfaces by setting the flow rate to 7, 30, 50 and $100 \mu \mathrm{L} \mathrm{min}{ }^{-1}$ (Fig. 4). These flow speeds correspond to shear forces of $\approx 7-100 \mathrm{mPa}$. Fluid flow exerted a biphasic effect on bacterial binding to mucin modified Au SPR interfaces. For all three bacteria and four mucin types investigated, an increased binding avidity was observed at $30 \mathrm{mPa}$, followed by a decrease in avidity at higher forces $(\mathrm{p} \leq 0.0001 ; \mathrm{n}=3$, Fig. 4A-F). The overall effect of increased flow on binding was lower for $V$. harveyi (1.2 to 1.6-fold increase at $30 \mathrm{mPa}$ ) compared to the other two studied pathogens (2.0 to 7.6-fold increase at $30 \mathrm{mPa}$ ) (Fig. 4B, D, F). For all three bacteria, the interaction with pyloric cecal mucins was least affected by flow. The effect of flow on $V$. harveyi binding to skin mucins was more pronounced compared to the other mucin groups. For A. salmonicida and A. hydrophila the interaction most affected by flow was that to proximal intestinal mucins, whereas the effect on binding to skin mucins was intermediate (Fig 4C-D). At $100 \mathrm{mPa}$, A. salmonicida retained a binding avidity to all mucins higher than the one at static conditions $(\mathrm{p} \leq 0.0001 ; \mathrm{n}=3$, Fig. 4A-B). A. hydrophila avidity to skin and distal intestinal samples at $100 \mathrm{mPa}$ was higher than at static conditions (p $\leq 0.0001 ; n=3-4$, Fig. 4D), while the binding to proximal intestinal and pyloric cecal mucins was similar (p = ns; $n=3$, Fig. 4C-D) and lower ( $\leq 0.01 ; n=3$, Fig. 4C-D) than that at static conditions, respectively. $V$. harveyi binding to skin mucins at $100 \mathrm{mPa}$ was similar to the level of binding at static condition $(\mathrm{p}=\mathrm{ns} ; \mathrm{n}=3$, Fig. $\mathbf{4 E - F})$, while the avidity to all other mucin samples was lower than at static conditions ( $\mathrm{p} \leq 0.0001$; $\mathrm{n}=3$, Fig. 4E-F). Thus, overall, binding to mucins is affected by flow, and this is most pronounced for mucins with low binding avidity at static conditions. 
Cell surface binding interactions that increase in avidity with shear force are known as "catch bonds" (Dembo et al., 1988). The avidity of a catch bond does not increase indefinitely but until a certain breaking point (Sokurenko et al., 2008). Interestingly, this catch bond acts like a seat belt reacting with higher bond strength to a more sudden increase in shear force (Dansuk and Keten, 2018). An example of this binding type is the E. coli mannose-binding FimH twodomain adhesin (Yakovenko et al., 2008; Szunerits et al., 2016). Shear activation of FimH is dominated by shear force and off-rates (i.e. not kinetic effects and on-rates) and the increased binding is likely caused by force-induced elimination of hydrogen bonds in the interdomain region, leading to an extended conformation in the tip of the fimbriae. Since A. salmonicida and A. hydrophila possess type 1 pili bio-machineries similar to that of E. coli (Dacanay et al., 2010; Ho et al., 1990), similar catch bonds may be formed by these pathogens. However, since mannose is absent in our mucin samples (Benktander et al., 2019), these bonds can only be established with non-mannose targets. In A. salmonicida it is likely NeuAc, as we previously established that NeuAc is the primary epitope A. salmonicida bind to on mucins (Padra et al., 2014). Among the pathogens studied here, A. salmonicida showed the highest increase in adhesion with increased flow rate (Fig. 4B). This pathogen, unlike A. hydrophila and V. harveyi, lacks flagella, therefore a shear-force enhanced binding may be important for it to establish connection with the host through skin mucins.

Compared to the fluid velocity the skin of Atlantic salmon in aquaculture can be exposed to, the fluid velocities studied here ranged from static to moderate (Solstorm et al., 2015). Atlantic salmon can be exposed to velocities higher than this, although exposure to high fluid velocity for extended periods results in reduced Atlantic salmon growth (Solstorm et al., 2015). The peristaltic waves in the gut of brown trout travel only at a speed of $2 \mathrm{~cm} / \mathrm{min}$ (Burnstock, 1958), however, the muscle contractions in the gastointestinal tract may also add to the shear force, making it difficult to estimate shear forces in this body region. 

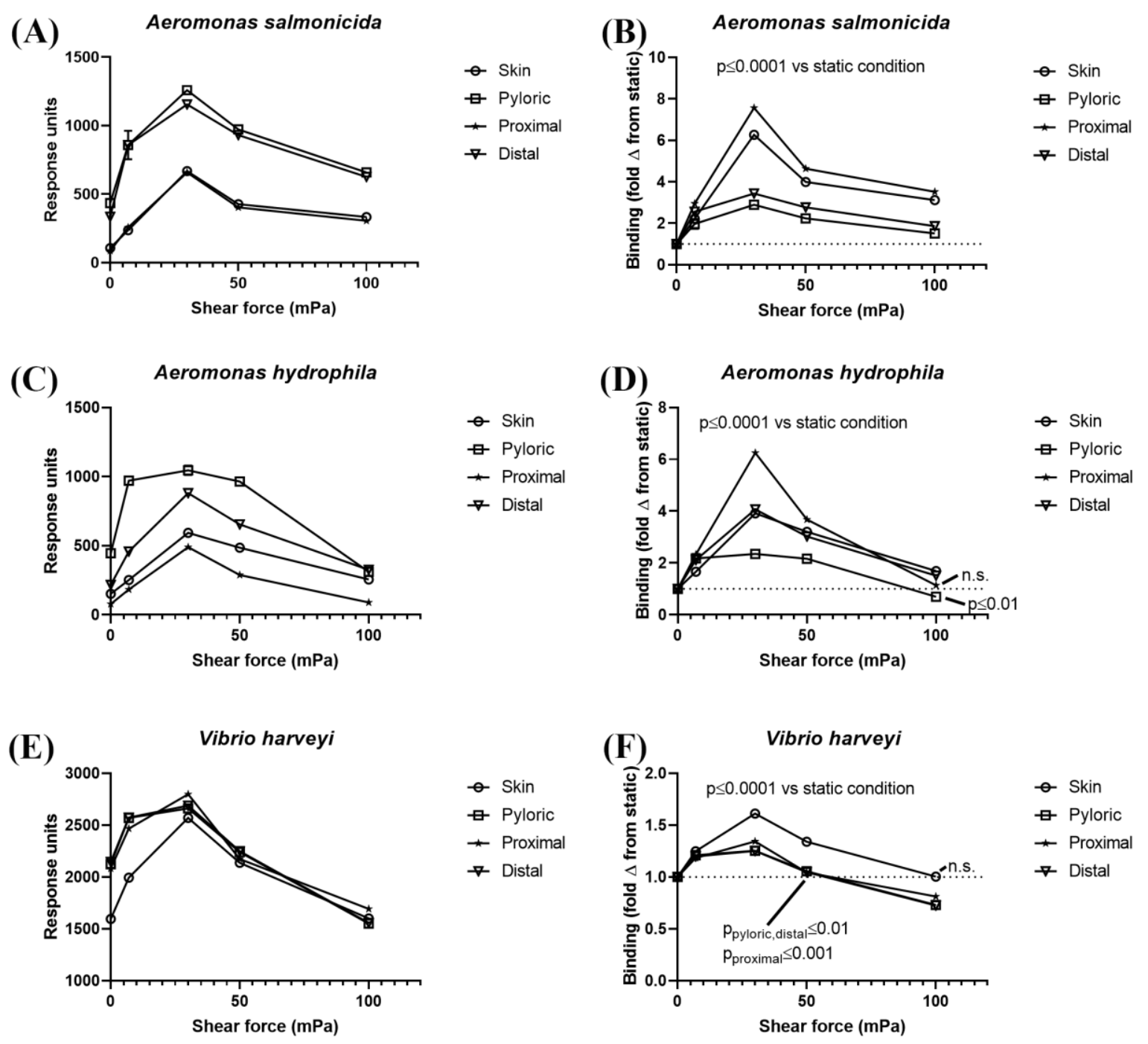

Figure 4. Changes in bacterial binding to mucins by fluid shear force. (A), (C) and (E) show raw binding data, whereas the corresponding (B), (D) and (F) show values normalized for static conditions. (A) - (B). A. salmonicida, (C) - (D). A. hydrophila and (E) - (F). V. harveyi avidity to mucins from the different epithelia. Data points are expressed as means \pm SEM $(n=3)$. The error bars are often small and therefore covered by symbols. Statistics: One-way ANOVA with Dunnett's multiple comparisons test against static condition. The data points are statistically different with $\mathrm{p} \leq 0.0001$ from static conditions unless otherwise marked on the right-side panels. Abbreviations: pyloric: pyloric cecal mucins, proximal: proximal intestinal mucins, distal: distal intestinal mucins. The results were reproduced 3 times.

\subsection{Comparison and analysis of SPR and ATP-based assays}

The ATP-based bioluminescence assay measures the number of live bacteria that bind to mucins. Mucins affect pathogen growth differentially depending on the epithelial site that the mucins have been isolated from (Padra et al., 2017). The relatively small differences in binding to different epithelial sites between the two methods compared could potentially be explained by the fact that the SPR method measures binding of all bacteria, 
whereas the ATP-based assay measures only live bacteria (Fig. 2). An advantage of the ATP-based assay is that it can easily be converted to bound colony-forming units/area for comparisons in binding level between species (Padra et al., 2019a), whereas results from the SPR are affected by the size of the pathogen. On the other hand, the variation between technical replicates is smaller with the SPR method (Fig. 5). Furthermore, analysis of the role of flow in adhesion has been hampered by challenges in accurately converting circular flow to linear flow: in a previous study analysing the effect of flow on a rotating shaking incubator using two mucins and two pathogens, we also identified an initial increase in binding with shaking at low speeds followed by a decrease at higher flow in the case of A. hydrophila (Padra et al., 2019a). However, the speed calculated by converting rpm to linear flow $(\mathrm{v}=\mathrm{f} 2 \pi \mathrm{r}$, where " $\mathrm{v}$ " is linear velocity, " $\mathrm{f}$ " is frequency in round $\mathrm{s}^{-1}$, and " $\mathrm{r}$ " is radius of the plate well) resulted in an approximately 7-fold higher speeds for the peak vs decline in avidity in the plate based assay compared to the SPR assay, suggesting that a more complex formula needs to be used to convert angular flow to linear flow in these types of assays. Another weakness of the ATP-based assay during circular flow conditions is the inhomogeneous distribution of bacteria in the well: increasing the rpm results in the bacterial suspension shifting towards the edge of the well. Additionally, bacteria closer to the plate centre travel a shorter route compared to the ones closer to the edge for each rotation exerting higher shear force on the latter. A further benefit of the SPR method is the real-time measurement of the binding: detection under continuous flow does not allow room for bacteria to loosen their catch bonds and release themselves from the mucins. The washing and detection step however provide ample time for bacteria to release these bonds in the microtiter-based assay. 


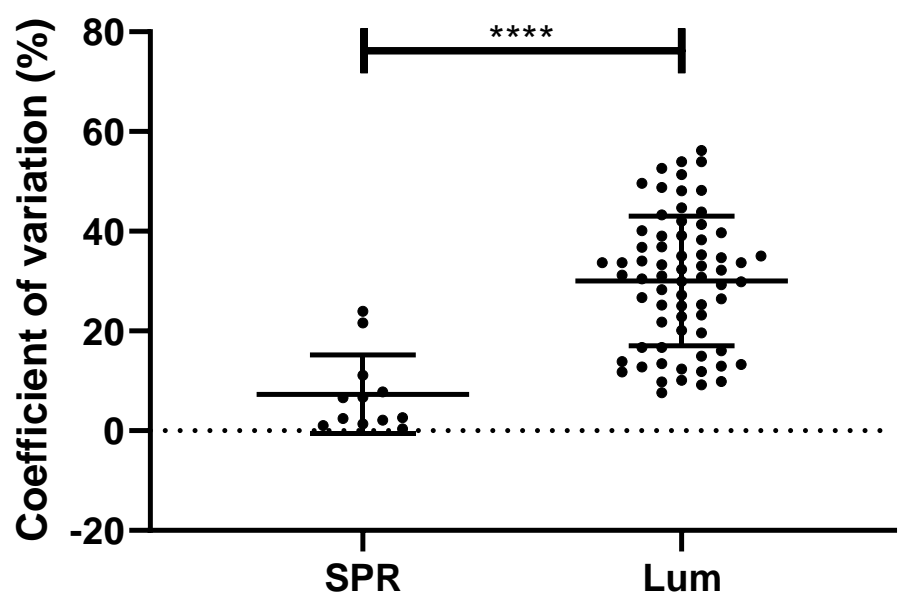

Figure 5. Error of SPR signals vs. ATP-based quantification of mucin-bound bacteria. The coefficient of variation for technical replicates of ATP-detection (Lum) from mucin-bound A. hydrophila, A. salmonicidia and $V$. harveyi is higher than that of SPR $(\mathrm{p} \leq 0.0001 ; \mathrm{n}=69$ and $\mathrm{n}=12$, respectively). Data points represent coefficient of variation $(\mathrm{CV} \%)$ values of technical replicates of $A$. hydrophila, A. salmonicidia and $V$. harveyi binding to Atlantic salmon skin, pyloric cecal, proximal intestinal and distal intestinal mucins under static conditions. Data points are expressed as means \pm SD. Statistics: Unpaired Student's T test. Abbreviations: SPR: Surface plasmon resonance binding signals; ATP: ATP-based quantification of bound bacteria.

\section{Conclusion}

In the present study, we demonstrate that performing bacterial binding assays to mucins using SPR is feasible and has advantages over other binding assay methods, both at static and flow conditions. At static conditions, binding assays using microtiter-based assays and SPR gave similar results and indicate that A. salmonicida, A. hydrophila and $V$. harveyi bind to mucins from all investigated epithelial sites. The variation between technical replicates was significantly smaller between technical replicates using SPR detection compared to ATP-based detection in microtiter-plate based assays. Furthermore, we demonstrated that the effect of flow on binding was relatively large and differed non-linearly with flow rates as well as between pathogens and epithelial sites. In vivo infection studies with fish held under flows similar to those in aquaculture are needed to further elucidate the role of mucins and mucin glycosylation in the defence against pathogens. 


\section{References}

Benktander, J., Venkatakrishnan, V., Padra, J. T., Sundh, H., Sundell, K., Murugan, A. V. M., Maynard, B., and Linden, S. K., 2019. Molecular \& cellular proteomics 18, 11831196.

Berg, A., Rodseth, O. M., Tangeras, A., and Hansen, T., 2019. Dis. Aquat. Org. 69, 239-248.

Bjørge, M. H., Nordgreen, J., Janczak, A. M., Poppe, T., Ranheim, B., and Horsberg, T. E., 2011. App. Anim. Behav. Sci. 133, 127-135.

Bravo-Osuna, I., Noiray, M., Briand, E., Woodward, A. M., Argueso, P., Molina Martinez, I. T., Herrero-Vanrell, R., and Ponchel, G., 2012. Pharm Res. 29, 2329-2340.

Burnstock, G., 1958. Br. J. Pharmacol 13, 216-226.

Çagatay, T. and Şen, E. B., 2014. Int. J. Agril. Biol. 16, 435-438.

Chayed, S. and Winnik, F. M., 2007. Eur J Pharm Biopharm. 65, 363-370.

Chisada, S., Shimizu, K., Kamada, H., Matsunaga, N., and Okino, N., 2013. FEMS Microbiol. Lett. 341, 18-26.

Dacanay, A., Boyd, J. M., Fast, M. D., Knickle, L. C., and Reith, M. E., 2010. Dis. Aquat. Org. 88, 199-206.

Dansuk, K. C. and Keten, S., 2018. Soft Matter 14, 1530-1539.

Dedinaite, A., Lundin, L., Macakova, L., and Auletta, T., 2005. Langmuir 21, 9503.

Dembo, M., Torney, D. C., Saxman, K., and Hammer, D., 1988. Proc R Soc Lond [Biol] 234, 55-83.

Fogarty, C., Burgess, C. M., Cotter, P. D., Cabrera-Rubio, R., Whyte, P., and Smyth, C., 2019. J. Appl. Microbiol. 127, 648-657.

Ho, A. S., Mietzner, T. A., Smith, A. J., and Schoolnik, G. K., 1990. J. Clin. Exp. Med . 172, 795-806.

Jin, C., Padra, J. T., Sundell, K., Sundh, H., Karlsson, N. G., and Linden, S. K., 2015. J. Proteome. Res. 14, 3239-3251.

Lavoie, C., Courcelle, M., Redivo, B., and Derome, N., 2018. Evol. Appl. 11, 1671-1685.

Lee, K. K., Liu, P. C., and Chuang, W. H., 2002. Mar. Biotechnol. 4, 267-277.

Linden, S., Mahdavi, J., Semino-Mora, C., Olsen, C., Carlstedt, I., Boren, T., and Dubois, A., 2008a. PLoS Pathog. 4, e2.

Lindén, S., Nordman, H., Hedenbro, J., Hurtig, M., Borén, T., and Carlstedt, I., 2002. Gastroenterology 123, 1923-1930. 
Linden, S., Semino-Mora, C., Liu, H., Rick, J., and Dubois, A., 2010. Helicobacter 15, 251258.

Linden, S. K., Sheng, Y. H., Every, A. L., Miles, K. M., Skoog, E. C., Florin, T. H., Sutton, P., and McGuckin, M. A., 2009. PLoS Pathog. 58, e1000617.

Linden, S. K., Sutton, P., Karlsson, N. G., Korolik, V., and McGuckin, M. A., 2008b.

Mucosal Immunol. 1, 183-197.

Midtlyng, P. J., 1997. Dev. Biol. Stand. Abbreviation 91, 371-379.

Mittal, K. R., Lalonde, G., Leblanc, D., Olivier, G., and Lallier, R., 1980. Can. J. Microbiol. $26,1501-1503$.

Navarrete, P., Espejo, R. T., and Romero, J., 2009. Microb. Ecol. 57, 550-561.

Padra, J. T., Murugan, A. V. M., Sundell, K., Sundh, H., Benktander, J., and Linden, S. K., 2019a. PloS one 14, e0215583.

Padra, J. T., Sundh, H., Jin, C., Karlsson, N. G., Sundell, K., and Linden, S. K., 2014. Infect. Immun. 82, 5235-5245.

Padra, J. T., Sundh, H., Sundell, K., Venkatakrishnan, V., Jin, C., Samuelsson, T., Karlsson, N. G., and Linden, S. K., 2017. Infect. Immun. 85, e00189-00117.

Padra, M., Adamczyk, B., Flahou, B., Erhardsson, M., Chahal, G., Smet, A., Jin, C., Thorell, A., Ducatelle, R., Haesebrouck, F., Karlsson, N. G., and Linden, S. K., 2019 b.

Mucosal Immunol. 12, 784-794.

Padra, M., Benktander, J., Robinson, K., and Linden, S. K., 2019c. Curr. Top. Microbiol. 421, 179-120.

Quintana-Hayashi, M. P., Padra, M., Padra, J. T., Benktander, J., and Linden, S. K., 2018. Microorg. 6, 55.

Ringø, E., Olsen, R. E., Øverli, Ø., and Løvik, F., 1997. Aquac. Res. 28, 901-904.

Safina, G., 2012. Anal. Chim. Acta 712, 9-29.

Skoog, E. C., Padra, M., Åberg, A., Gideonsson, P., Obi, I., Quintana-Hayashi, M. P., Arnqvist, A., and Lindén, S. K., 2017. Sci. Rep. 7, 40656.

Sokurenko, E. V., Vogel, V., and Thomas, W. E., 2008. Cell Host Microbe 4, 314-323.

Solstorm, F., Solstorm, D., Oppedal, F., Ferno, A., Fraser, T. W. K., and Olsen, R. E., 2015. Aquacult. Env. Interac. 7, 125-134.

Stettner, J., Frank, P., Griesser, T., Trimmel, G., Schennach, R., Gilli, E., and Winkler, A., 2009. Langmuir 25, 1427-1433.

Subramanian, P., Barka-Bouaifel, F., Bouckaert, J., Yamakawa, N., Boukherroub, R., and Szunerits, S., 2014. ACS Appl. Mater. Interfaces 6, 5422-5431. 
Szunerits, S., Zagorodko, O., Cogez, V., Dumych, T., Chalopin, T., Alvarez Dorta, D., Sivignon, A., Barnich, N., Harduin-Lepers, A., Larroulet, I., Yanguas Serrano, A., Siriwardena, A., Pesquera, A., Zurutuza, A., Gouin, S. G., Boukherroub, R., and Bouckaert, J., 2016. Biology 5, E14.

Takeuchi, H., Thongborisute, J., Matsui, Y., Sugihara, H., Yamamoto, H., and Kawashima, Y., 2005. Adv. Drug Deliv Rev. 57, 1583-1594.

Yakovenko, O., Sharma, S., Forero, M., Tchesnokova, V., Aprikian, P., Kidd, B., Mach, A., Vogel, V., Sokurenko, E., and Thomas, W. E., 2008. J. Biol. Chem. 283, 1159611605 .

Zagorodko, O., Bouckaert, J., Dumych, T., Bilyy, R., Larroulet, I., Serrano, A. Y., Dorta, D. A., Gouin, S. G., Dima, S.-O., Oancea, F., Boukherroub, R., and Szunerits, S., 2015. Biosensors 5, 276-287.

Zepeda-Velázquez, A. P., Vega-Sánchez, V., Salgado-Miranda, C., and Soriano-Vargas, E., 2015. Can. J. Vt. Res. 79, 250-254.

Zhang, D., Xu, D.-H., and Shoemaker, C., 2016. Aquacult. Rep. 3, 18-23.

Zhang, X. H. and Austin, B., 2000. J. Fish Dis. 23, 93-102. 